\title{
PENGARUH PERCEIVED OF BENEFIT TERHADAP NIAT UNTUK MENGGUNAKAN LAYANAN DOMPET DIGITAL DI KALANGAN MILENIAL
}

\author{
Femmy Effendy
}

Sekolah Tinggi Manajemen Informatika dan Komputer Rosma, Karawang

Email:femmy@rosma.ac.id

\begin{abstract}
This study aims to (1) To explain how the influence of perceived of benefit on intention to use e-wallet. (2) To explain how the influence between intention to use on ewallet behavior. This type of research is an explanatory research with a quantitative approach. The variables of this study include Perceived Benefits, Intention to use and behavior use. The population in this study are Millennials with age range 17-23 years and have used e-wallet. Samples used in this study were 116 respondents taken using purposive sampling techniques and data collection methods using survey and questionnaire methods. Data were collected using a purposive sampling technique and with questionnaire and measurement instruments using a semantic differential scale. The path analysis approach is processed by structural model equations using Lisrel 8.7. The results showed that the perceived benefit had a significant effect on Intention to use e-wallet and Beheading use ewallet. This study concludes that the benefit factor in using $e$-wallet to millennials remains a consideration decision.
\end{abstract}

Keywords: e-wallet, Perceived Benefit, Intention To use, Behaviour use

Abstrak

Penelitian ini bertujuan untuk (1) Untuk menjelaskan bagaimana pengaruh antara Perceived Benefit terhadap Intention to use dompet digital. (2) Untuk menjelaskan bagaimana pengaruh antara Intention to used terhadap behaviour use dompet digital. Jenis penelitian yang digunakan adalah penelitian penjelasan dengan pendekatan kuantitatif. Variabel penelitian ini meliputi Perceived Benefit, Intention to use dan behaviour use . Populasi dalam penelitian ini adalah kaum Milenial dengan rentang umur 17-37 tahun dan pernah menggunakan dompet digital. Sampel yang digunakan dalam penelitian ini sebanyak 116 orang responden yang diambil dengan menggunakan teknik purposive sampling dan metode pengumpulan data menggunakan metode survei dan kuesioner. Data dikumpulkan dengan menggunakan teknik purposive sampling dan dengan instrumen angket dan pengukuran menggunakan skala semantic deferensial. Pendekatan analisis jalur yang diolah dengan persamaan model struktural menggunakan Lisrel 8.7. Hasil penelitian menunjukkan bahwa perceived benefit berpengaruh signifikan terhadap Intention to use dompet digital dan Behaviour use. Penelitian ini menyimpulkan bahwa faktor manfaat dalam menggunakan dompet digital pada kaum milenial tetap menjadi pertimbangan keputusan.

Kata Kunci: Dompet Digital, Perceived Benefit, Intention To use, Behaviour use 


\section{PENDAHULUAN}

Peningkatan di bidang teknologi internet dan juga berkembangnya industri smartphone yang dibarengi dengan gaya hidup cashless society yang sangat pesat belakangan ini, memiliki pengaruh besar atas munculnya sistem pembayaran online di Indonesia. Industri pembayaran seperti dompet digital semakin berkembang dengan hadirnya perusahaan yang berusaha menjangkau mereka yang belum memiliki rekening bank (unbanked society), survei PricewaterhouseCoopers (PwC) terkait dengan Global Consumer Insights yang dikutip Kamis (Ekonomi dan Bisnis, 13 Juni 2019), mengambarkan bahwa $47 \%$ responden di Indonesia saat ini menggunakan pembayaran secara online untuk bertransaksi pada 2019.

Layanan pembayaran tanpa uang tunai semakin populer di Indonesia, berbagai bisnis dan layanan di seluruh kota menawarkan alternatif pembayaran kepada orang Indonesia. Menurut Bank Indonesia, perusahaan operator dompet digital terdiri dari 22 perusahaan teknologi keuangan (fin-tech), 11 bank, dan 5 perusahaan telekomunikasi. Operator dompet digital bersaing untuk memperluas pangsa pasarnya dengan melakukan strategi promosi besar-besaran termasuk cashback dan kemitraan dengan perusahaan yang memiliki banyak basis pengguna seperti e-commerce, biro perjalanan online, dan lain sebagainya

Pada 2017, Jakpat aplikasi jenis open survei platform melakukan survei untuk memprediksi tren penggunaan uang digital di Indonesia. Hasilnya, sebagian besar responden berencana menggunakan uang digital lebih sering untuk kebutuhan sehari-hari dan pembayaran utilitas bangunan seperti pembayaran listrik, air, tv kabel, internet, dan lain sebagainya. Pada 2018, Jakpat juga melakukan survei terhadap 1.894 responden di seluruh Indonesia untuk melihat tren pembayaran online, memprediksi tren penggunaan mobile payment, dan mengetahui siapa pemain dominan di industri mobile payment yang ada di Indonesia. Jenis layanan mobile payment termasuk didalamnya dompet digital yang paling banyak digunakan oleh responden sebanyak 73,8\% responden untuk mengisi pulsa, $68,6 \%$ responden untuk belanja online dan $65,8 \%$ responden untuk mentransfer uang, Survei diikuti oleh 1.714 responden, dan mereka diperbolehkan untuk memilih lebih dari satu pilihan (Jakpat.net), dan laporan terbaru menunjukkan bahwa 93\% responden yang di surey menggunakan transaksi dompet digital dan survey juga menunjukkan 9 dari 10 orang pengguna internet juga menggunakan dompet digital (Jakpat,2019) 


\section{THE USE OF DIGITAL WALLET IN INDONESIA}

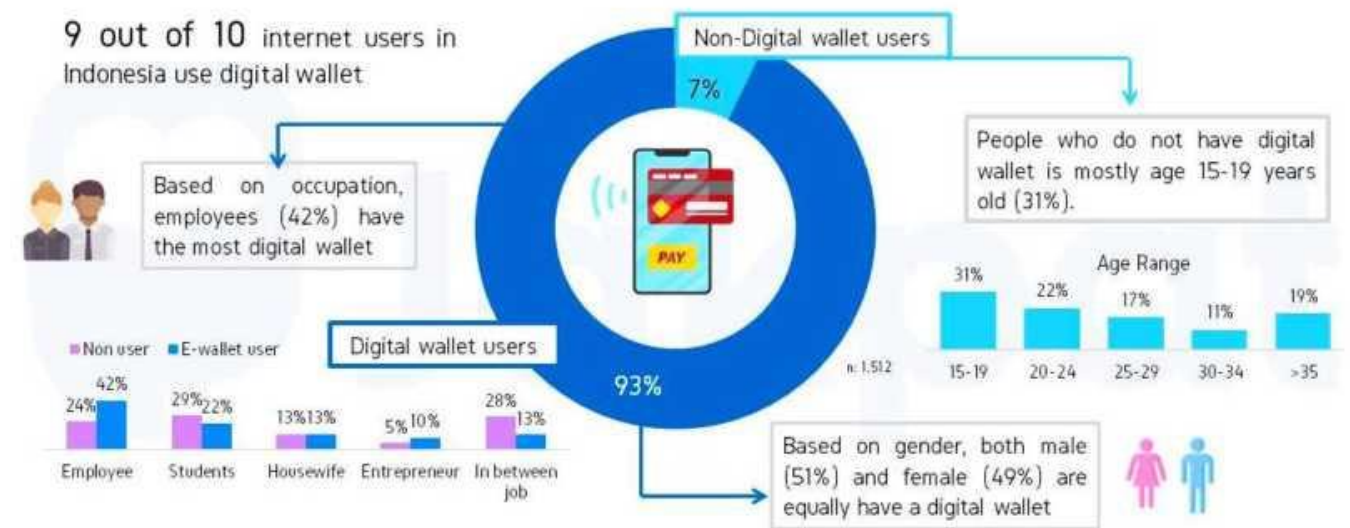

Jakpat

Gambar 1. The Use of Digital Wallet in Indonesia, JAKPAT, 2020

Penelitian yang dilakukan oleh Susilo dkk [1] menyatakan bahwa persepsi penggunaan yang mudah, mempengaruhi sikap terhadap penggunaan aktual dompet digital seperti GO-PAY dan OVO. Di bagian lain Z Bezhovski [2] Perkembangan Internet dan kedatangan e-commerce mendorong digitalisasi dalam proses pembayaran dengan

\section{berbagai opsi}

pembayaran elektronik termasuk kartu pembayaran (kredit dan debit), dompet digital dan seluler, uang elektronik, metode pembayaran tanpa kontak.

Pembayaran seluler layanan dengan popularitas mereka yang meningkat saat ini berada di bawah fase transisi, menuju masa depan yang menjanjikan dari kemungkinan sementara bersama dengan inovasi dalam teknologi. Kebiasaan adalah faktor yang paling kuat mempengaruhi niat perilaku individu untuk menggunakan dompet ponsel di Indonesia, diikuti oleh pengaruh sosial, ekspektasi usaha dan motivasi hedonis menurut Megadewandanu dkk[3]. Berdasarkan penelitian sebelumnya bahwa sikap, kemudahan dan perkembangan internet yang pesat pada teori dan fakta empiris dari niat menggunakan dompet digital, maka penelitian ini bertujuan untuk menguji pengaruh perceived of benefit pada niat untuk menggunakan pembayaran melalui dompet digital pada kalangan milenial. Bagian berikut dari artikel ini termasuk tinjauan teoretis, pengembangan hipotesis, metode dengan LISREL, analisis, diskusi dan penelitian lebih lanjut.

\section{TINJAUAN PUSTAKA}

Perilaku Konsumen

Pengertian perilaku konsumen menurut Schiffman dan Kanuk (1994:7)[4],mendefinisikan perilaku konsumen sebagai berikut: "The term consumer behavior refers to the behavior that consumers display in searching for, purchasing, using, evaluating, and disposing of products and services that they expect will satisfy their needs". Studi tentang bagaimana individu, kelompok, dan organisasi memilih, membeli, dan menggunakan barang, jasa, ide atau pengalaman untuk memuaskan kebutuhan dan keinginan mereka. Persepsi/Perceived

Andrej Demuth [4] menyatakan persepsi adalah "sebuah proses individu mengorganisasikan dan menginterpretasikan kesan sensoris untuk memberikan pengertian kepada 
lingkungannya" .Persepsi melibatkan kognisi (pengetahuan). Oleh karena itu, persepsi merupakan interpretasi dari objek, simbol, dan orang yang didasarkan pada pengalaman. persepsi menangkap stimulus, mengorganisasikan stimulus, dan menginterpretasikan stimulus yang terorganisir untuk mempengaruhi perilaku (behaviour) dan membentuk sikap (attitute)

Perceived of Benefit

Manfaat yang dirasakan diklasifikasikan ke dalam tiga aspek berbeda: 1) manfaat ekonomi; 2)

kenyamanan, dan 3) proses transaksi. Manfaat ekonomi adalah motif paling umum dan konsisten yang diidentifikasi , transaksi dengan menggunakan dompet Intention to use

Menurut Taylor dan Baker [6] behaviour intention to use diartikan sebagai keinginan individu untuk menggunakan kembali sesuatu yang sama apabila suatu waktu memerlukan kembali. Doods et al. [7] dalam A Fitri (2014) menjelaskan bahwa minat pembelian atau penggunaan ulang merupakan kemungkinan pembeli atau pengguna berintensitas untuk membeli kembali atau menggunakan kembali suatu produk atau jasa.

Dompet Elektronik (e-wallet)

Dompet elektronik atau $e$-wallet adalah suatu jenis akun pembayaran elektronik dimana pengguna dapat menyimpan uang untuk setiap transaksi di masa depan. $E$ wallet dilindungi dengan kata sandi. Dengan bantuan e-wallet, seseorang dapat melakukan pembayaran untuk bahan makanan, pembelian online, dan tiket penerbangan, dll. E-wallet memiliki dua komponen utama yaitu perangkat lunak dan informasi. Komponen perangkat lunak menyimpan informasi pribadi dan menyediakan keamanan dan enkripsi data. Komponen informasi adalah basis data rincian yang diberikan oleh pengguna yang mencakup nama, alamat pengiriman, metode pembayaran, jumlah yang harus dibayarkan, detail kartu kredit digital lebih murah dibandingkan dengan layanan keuangan tradisional, sehingga menguntungkan pengguna. Selain itu, kenyamanan ditunjukkan sebagai salah satu manfaat nyata yang didorong dari portabilitas dan aksesibilitas langsung. Kenyamanan mengacu pada fleksibilitas dalam waktu dan lokasi, Mengingat bahwa perangkat seluler merupakan salah satu saluran penting dalam penggunaan, kenyamanan melalui perangkat seluler menentukan tingkat manfaat yang dirasakan. Proses transaksi mengacu pada manfaat terkait transaksi. Dibandingkan dengan transaksi keuangan tradisional, kecepatan transaksi lebih efisien dan lancar [5] Hyun-Sun Ryu

atau debit, dll. Untuk menyiapkan akun $e$ wallet, pengguna perlu menginstal perangkat lunak pada perangkat telekomunikasi seperti smartphone, dan memasukkan informasi yang relevan yang diperlukan. Setelah berbelanja online atau offline, $e$-wallet secara otomatis mengisi informasi pengguna pada formulir pembayaran (The Economics Times, 2018). Generasi Milenial

Generasi ini lahir setelah zaman generasi $\mathrm{X}$, atau tepatnya pada kisaran tahun 1980 sampai tahun 2000-an. Jadi dapat diperkirakan bahwa saat ini generasi millennial memiliki rentang usia 17 hingga 37 tahun. Di Indonesia sendiri, Dalam Profil Generasi Milenial 2018, BPS menyebutkan bahwa generasi milenial mencapai 33,75 persen dari jumlah penduduk keseluruhan. Ini berarti sumbangan generasi milenial dalam membentuk struktur jumlah penduduk usia produktif cukup tinggi, dimana dari 67,02 persen penduduk usia produktif, sekitar 50,36 persennya adalah generasi milenial. Kondisi ini menunjukkan adanya bonus demografi (sumber: Badan Pusat Statistik) 
Hipotesis Penelitian

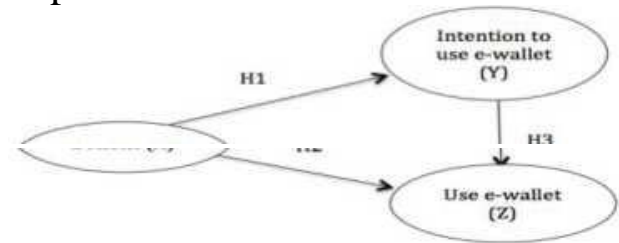

Gambar 2. Model Penelitian Sumber :

Peneliti, 2020

\section{METODE PENELITIAN}

Data dalam penelitian ini menggunakan data primer yaitu data yang diperoleh secara langsung, dengan cara melakukan survei terhadap responden, kuisioner pertanyaan yang dibagikan merupakan kuesioner pertanyaan yang diukur dengan skala semantic diferensial atau diferensial semantic. Diferensial semantic (SD) pertama kali diperkenalkan dan dikembangkan oleh psikolog AS Charles E. Osgood (1916-1991), SD adalah jenis skala penilaian semantik yang dapat mengukur makna konotatif konsep seperti istilah, objek, peristiwa, aktivitas, ide, dan juga yang lainnya dan mampu untuk menangkap komponen afektif dan kognitif atribusi responden terhadap konsep yang dipilih pada tingkat multidimensi. Berbeda dari skala penilaian lainnya yang biasa digunakan seperti likert, SD mampu berlaku universal dan dapat mengukur asosiasi, motivasi, emosi, sikap, dselain itu juga bisa digunakan untuk hampir pada semua konsep [8]. Populasi penelitian adalah kaum milenial kota karawang dengan tingkatan usia 17-37 tahun, dan dari berbagai pekeijaan dengan kriteria pernah dan aktif menggunakan dompet digital seperti OVO, DANA, Go-Pay dan lainnya sampai saat kuesioner dibagikan. Sampel yang diambil secara non probability sampling dan purposive sampling, pengambilan sampel berfokus pada responden yang memiliki kesamaan sifat atau karakteristik tertentu [9]. Sampel yang didapatkan sebanyak 116 pengguna aktif dompet digital saat ini. Data kepustakaan dan kuisioner digunakan untuk teknik pengumpulan data dalam penelitian ini. Kepustakaan digunakan dari sumber-sumber seperti literatur, dokumen, artikel, jurnal, buku, dan perangkat lainnya yang akan mendukung data sekunder dalam penelitian. Pengambilan sampel yang mewakili populasi dengan pemahaman tentang sifat atau karakteristiknya akan memungkinkanuntukmenggeneralisasikan sifat atau karaktersistik tersebut pada elemen populasi yang akan diteliti. Sampel adalah suatu bagian dari keseluruhan serta memiliki

karakteristik yang dimiliki oleh sebuah Populasi [10]. Teknik pengambilan data dilakukan dengan cara menyebarkan kuesioner. Kuesioner adalah suatu teknik pengumpulan informasi yang memungkinkan analis mempelajari sikapsikap, keyakinan, perilaku, dan karakteristik beberapa orang dan merupakan proses pengumpulan data dengan cara memberikan atau menyebarkan sejumlah pertanyaan kepada responden untuk memperoleh respon atas pertanyaan yang diberikan.

Pada penelitian ini skala yang digunakan adalah skala Semantic Diferensial, ada lima, skala yang digunakan yang berisikan serangkaian karakteristik bipolar (dua kutub) seperti Sukar-Mudah, Tidak ramah-Ramah, dan sebagainya, yang tersusun pada satu garis kotinom dimana jawaban yang sangat positif berada diposisi paling kanan dan jawaban yang sangat negatif pada posisi paling kiri, atau sebaliknya [8]. Teknik analisis data yang dilakukan dalam penelitian ini dengan menggunakan SEM. SEM menggabungkan aspek-aspek regresi berganda (menguji hubungan korelasi) dan analisis faktor (menggambarkan konsep yang tidak dapat diukur faktor dengan variabel berganda) untuk mengestimasi hubungan saling ketergantungan secara serentak [11], [12]. Penelitian ini menggunakan SEM dikarenakan variabel perceived of benefit, variabel intention/niat dan variabel Behaviour use menggunakan adalah variabel yang berupa variabel laten, atau variabel yang tidak bisa diukur secara 
langsung melainkan diukur dengan menggunakanfaktor-faktorpendukungnya.

Secara sistematik, analisis jalur atau path analysis mengikuti pola model struktural. Analisis jalur bisa dikatakan sebagai pengembangan dari konsep korelasi dan regresi, dimana korelasi dan regresi tidak mempermasalahkan mengapa hubungan antar variabel terjadi serta apakah hubungan antar variabel tersebut disebabkan oleh variabel itu sendiri atau mungkin dipengaruhi oleh variabel lain. Berbeda dengan korelasi dan regresi, analisis jalur mempelajari apakah hubungan yang terjadi disebabkan oleh pengaruh langsung dan tidak langsung dari variabel independen terhadap variabel dependen, mempelajari ketergantungan sejumlah variabel dalam suatu model (model kausal), dan menganalisis hubungan antar variabel dari model kausal yang telah dirumuskan oleh peneliti atas dasar pertimbangan teoritis. Melalui analisis jalur kita akan menguji seperangkat hipotesis kausal dan menginterpretasikan hubungan tersebut (langsung atau tidak langsung). Analisis jalur dapat membantu peneliti menggunakan data kuantitatif (korelasional) untuk mengurai berbagai (kausal) proses yang mendasari hasil tertentu dan memperkirakan besarnya dan kekuatan efek dalam sistem sebab akibat yang dihipotesiskan. Selain itu, analisis jalur juga mampu untuk menguji kesesuaian antara dua atau lebih model sebab-akibat, yang dihipotesiskan oleh peneliti agar sesuai dengan data sehingga langkah pertama yang dilakukan dalam mengerjakan atau menerapkan model, adalah dengan merumuskan terlebih dahulu persamaan struktural dan diagram jalur yang berdasarkan kajian teori tertentu [13]. Pengembangan diagram jalur dalam penelitian ini adalah menentukan pengaruh perceived of benefit terhadap intention/niat dan use/aktual menggunakan dalam penggunaan dompet digital. Indikator yang menjadi konstruk dalam penelitian ini adalah hal-hal yang memperi pengaruh tehadap perceoved of benefit terhadap intention/niat dan use/aktual penggunaan sistem dompet digital. Faktor-faktor apa saja yang dianggap mempengaruhi intention/niat dan use/aktual penggunaan dompet digital, dan untuk mengetahui apakah faktor perceived of benefit mempengaruhi intention/niat dan use/aktual penggunaan dompet digital tersebut atau tidak. Hipotesis sebagai berikut

- H1:Perceived Benefit berpengaruh secara positip dan signifikan terhadap Intention to Use dalam menggunakan Dompet digital.

- H2:PerceivedBenefit berpengaruh secara positip dan signifikan terhadap Behaviour use dalam menggunakan Dompet digital.

- H3: Intention to use berpengaruh secara positip dan signifikan terhadap Behaviour use

4. HASIL DAN PEMBAHASAN Profil responden

karakteristik responden dapat dilihat selengkapnya pada Tabel 1. 
Tabel 1. Karakteristik Responden

\begin{tabular}{|c|c|c|c|}
\hline Karakteristik & $\%$ & Karakteristik & $\%$ \\
\hline $\begin{array}{l}\text { Jenis kelamin } \\
\text { Laki-Laki } \\
\text { Perempuan }\end{array}$ & $\begin{array}{l}42 \% \\
58 \%\end{array}$ & $\begin{array}{l}\text { Pekerjaan } \\
\text { Pelaj ar/Mahasiswa } \\
\text { Karyawan } \\
\text { Yang lain } \\
\end{array}$ & $\begin{array}{l}58 \% \\
30.5 \% \\
11.5 \% \\
\end{array}$ \\
\hline $\begin{array}{l}\text { Pendapatan/Uang Saku } \\
\text { <Rp 500.000 } \\
\text { Rp 500.001- Rp 2.000.000 } \\
\text { Rp 2.000.001- Rp 5.000.000 } \\
\text { Rp 5.000.001-Rp 10.000.000 } \\
>\text { Rp 10.000.000 }\end{array}$ & $\begin{array}{l}11 \% \\
26 \% \\
40 \% \\
9 \% \\
14 \%\end{array}$ & $\begin{array}{l}\text { Tingkat pendidikan } \\
\text { Dibawah SMA Sederajat } \\
\text { SMA Sederajat-Diploma } \\
\text { S1 }\end{array}$ & $\begin{array}{l}2.3 \% \\
78 \% \\
19.7 \%\end{array}$ \\
\hline
\end{tabular}

Kecocokan Keseluruhan Model (Overall Model Fit)

Acuan indeks kecocokan model digunakan untuk mengetahui apakah model yang dibuat didasarkan pada data observasi sesuai dengan model teori atau tidak dan karena banyaknya indeks kecocokan model dalam SEM, pertimbangan-pertimbangan dalam menggunakan indeks kecocokan model tersebut sangat diperlukan. Sebaiknya kita menggunakan indeks kecocokan model yang umum, seperti RMSEA, Chi Square, dan CFI dalam pengujian kecocokan model. Indeks-indeks lain dapat digunakan, misalnya untuk melihat kesesuaian jumlah sampel ataupun nilai signifikansi [14]. Berikut Dari Tabel 2, tujuh ukuran GOF yang telah diuji dan menunjukkan kecocokan yang baik atau fit. Model SEM yang dibuat bertujuan untuk mengetahui kesesuaian dengan derajat kecocokan goodness of fit (GOF) yang baik, dengan data yang diambil dari sampel yang diteliti sehingga model yang dihasilkan dapat menjelaskan data yang diperoleh. Secara keseluruhan model pada penelitian ini menghasilkan kesimpulan model goodness of fit karena terdapat enam ukuran yang sudah memenuhi persyaratan dan dapat dikatakan bahwa pengujian hipotesis teori dapat dilakukan. Hal ini menunjukkan bahwa data hasil kuesioner sudah dapat menjawab teori yang dibangun maka model ini dapat digunakan untuk menjelaskan pengaruh dan hubungan antara variabel eksogen dan endogen.

Tabel 2. Hasil Kriteria Kesesuaian (Measurement Model Fit Indicate)

\begin{tabular}{|c|c|c|c|}
\hline \multirow[t]{2}{*}{$\overline{\overline{\text { Goodness-of-Fit Measures }}}$} & \multirow{2}{*}{$\begin{array}{l}\text { Cut-off } \\
\text { Value }\end{array}$} & \multicolumn{2}{|c|}{ Model } \\
\hline & & Hasil & Kecocokan \\
\hline p-value & $>0,05$ & 0.06 & Fit \\
\hline Goodness-of-Fit-Index (GFI) & $>0,90$ & 0.99 & Fit \\
\hline $\begin{array}{l}\text { Root Mean Square Error of App } \\
\text { (RMSEA) }\end{array}$ & $<0,08$ & 0.05 & Fit \\
\hline Normal Fit Index (NFI) & $>0,90$ & 0.98 & Fit \\
\hline Adjusted Goodness of Fit Indices (AGFI) & $>0,90$ & 0.80 & Tidak Fit \\
\hline Comparative Fit Index (CFI) & $>0,90$ & 0.93 & Fit \\
\hline Relative Fit Index (RFI) & $>0,90$ & 0.97 & Fit \\
\hline
\end{tabular}

Kecocokan Model Pengukuran (Measurement Model Fit) Evaluasi pengukuran atau konstruk secara terpisah dilakukan dengan evaluasi terhadap 
validitas (validity) dan juga dari model pengukuran dan evaluasi terhadap reliabilitas (reliability) [15], [16]. Hasil analisis Lisrel untuk path diagram standardized solution seperti pada gambar 3 dan diagram t-value Basic Model pada gambar 4. Analisis tersebut menghasilkan nilai untuk variabel korelasi atau kovarian dari masing- masing variabel laten eksogen variabel laten endogen dari model statistik penelitian. Rangkuman dari analisis oleh Lisrel 8.7 untuk path diagram standardized solution dan t- values ini dapat dilihat pada Tabel 3 .

Tabel 3. Uji Validitas

\begin{tabular}{ccccc}
\hline \hline Variabel & Indikator & $\begin{array}{c}\text { Std Loading } \\
\text { factor }\end{array}$ & t-Hitung & Keterangan \\
\hline X1 & X11 & 0.72 & 12.14 & Valid \\
& X12 & 0,65 & 11.13 & Valid \\
& X13 & 0.70 & 12.89 & Valid \\
& X14 & 0.72 & 11.70 & Valid \\
& X15 & 0.66 & 11.02 & Valid \\
Y1 & Y11 & 0.65 & & Valid \\
& Y12 & 0.73 & 11.64 & \\
Y2 & Y13 & 0.74 & 11.59 & Valid \\
& Y21 & 0.71 & & Valid \\
& Y22 & 0.65 & 10.42 & \\
& Y23 & 0.70 & 8.70 & Valid \\
& & & & Valid \\
\hline
\end{tabular}

Suatu variabel indikator dikatakan valid ketika memiliki nilai standardized loading factor lebih dari batas loading factor yang dapat ditoleransi yaitu $>0,50$ dan memiliki nilai $t$-value atau t-hitung lebih besar atau sama dengan nilai 1,96

[18] . Dari keluaran LISREL didapatkan loading factor yang menunjukkan besaran tingkat kontribusi dari masing-masing variabel indikator dalam membentuk variabel latennya. Gambar 3. menunjukkan hasil keluaran perangkat lunak Lisrel 8.7 yang menunjukkan nilai standarized loading factor pada CFA variabel laten Perceived of Benefit, Intention/Niat dan Use/Aktual. Nilai tersebut menunjukkan semua variabel manifest memiliki nilai standarized loading factor $>0,50$.

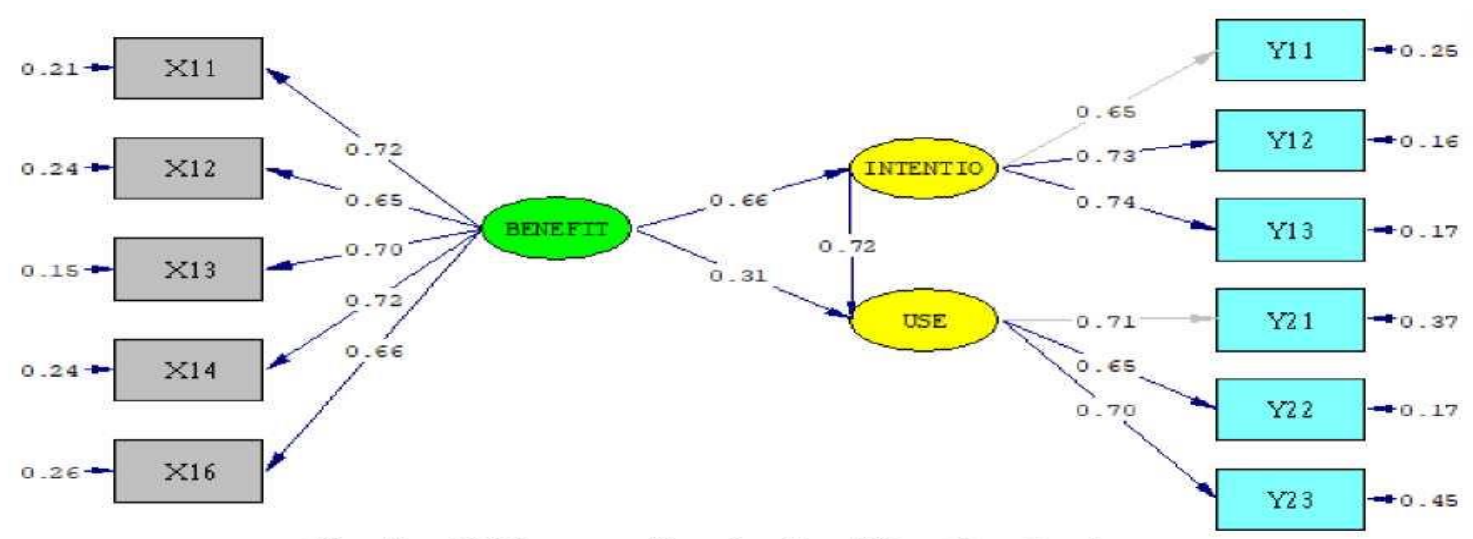

Gambar 3.Diagram Standardized Loading Factor 
Kecocokan Model Struktural (Structural Model Fit) Analisa terhadap model struktural termasuk pada signifikansi koefisien-koefisien yang diestimasi. Dari gambar 4. menunjukkan SEM (Structural
Equation Modelling) dengan Lisrel juga menyediakan nilai t-hitung untuk setiap koefisien yang diestimasi. Nilai t-hitung yang diharapkan dari setiap koefisien adalah $>1,96$.

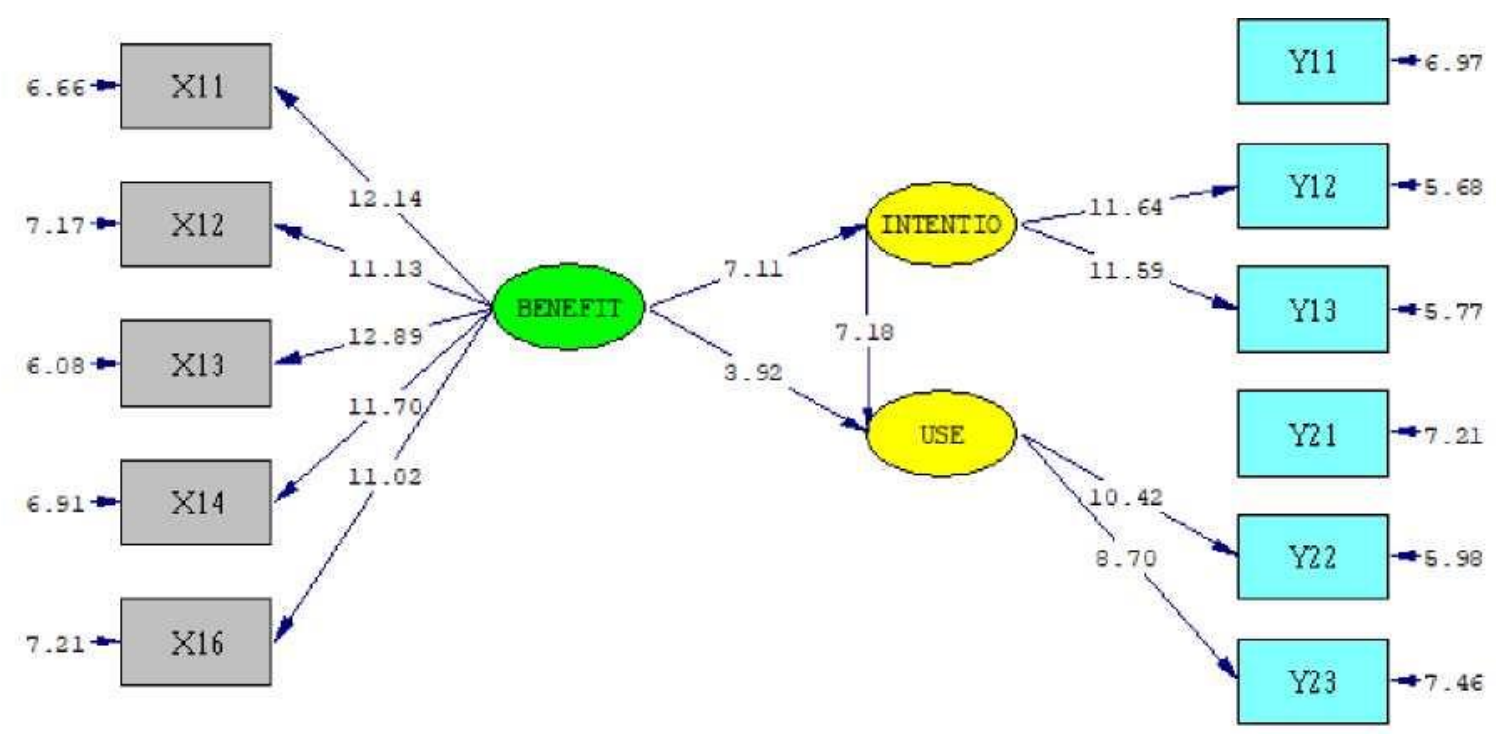

Gambar 4. Diagram t-value Basic Model

keterkaitan antara variabel laten eksogen dan variabel laten endogen dapat dilihat pada Tabel 4.

Berdasarkan data keluaran LISREL maka dapat dinyatakan hubungan kausal yang dihipotesiskan dapat dikatakan memiliki hubungan dan path diagram t-hitung,

\begin{tabular}{|l|l|l|l|}
\hline Hubungan Antar variabel & Koefisien Jalur & $\begin{array}{l}\text { t- } \\
\text { Hitung }\end{array}$ & Kesimpulan \\
\hline Perceived of benefit-> Intention/Niat & 0.66 & 7.11 & Signifikan \\
Perceived of benefit-> Intention/Niat & 0,31 & 3.92 & Signifikan \\
Intention/Niat-> Use/Aktual gunakan & 0.72 & 7.18 & Signifikan \\
\hline
\end{tabular}

Hasil pengujian uji signifikan, menunjukkan bahwa hipotesis yang terjadi seperti berikut:

H1: Perceived of benefit $\wedge$ intention/niat.

Pengaruh perceived of benefit pada Intention/niat untuk menggunakan pembayaran seluler melalui nilai t-hitung sebesar 7.11, nilai tersebut memenuhi syarat untuk penerimaan, dimana nilai $\mathrm{t}$ hitung yang diharapkan dari setiap koefisien yang diestimasi harus $>1.96$. Hasil penelitian tersebut sesuai dengan penelitian yang dilakukan yaitu mendapatkan nilai t-value sebesar $5.58>$
1,96 maka perceived of benefit berpengaruh signifikan terhadap intention/niat untuk menggunakan domoet digital. Pengaruh perceived of benefit merupakan sikap secara langsung terhadap intention/niat untuk mengunakan dompet digital dan membuktikan aplikasi yang ditawarkan membawa manfat dengan keinginan konsumen.Sehinggahipotesis ini dianggap dapat diterima.

H2: Perceived of benefit $\wedge$ Use/Aktual Menggunakan

Pengaruh perceived of benefit pada Intention/niat untuk menggunakan dompet digital melalui nilai t-hitung 
sebesar 3.92, nilai tersebut tidak memenuhi syarat untuk penerimaan, dimana nilai t-hitung yang diharapkan dari setiap koefisien yang diestimasi harus > 1.96.

H3: Intention/Niat-> Use/Aktual

Menggunakan

Pengaruh Intention/mat pada Use/Aktual menggunakan pembayaran seluler melalui nilai t-hitung sebesar 7.18 Nilai tersebut memenuhi syarat untuk penerimaan, dimana nilai t-hitung yang diharapkan dari setiap koefisien yang diestimasi harus > 1.96. Hasil penelitian tersebut sesuai dengan penelitian yang dilakukan yaitu mendapatkan nilai t-value sebesar $9.57>1,96$ maka intention/niat berpengaruh signifikan terhadap use/aktual penggunaan dompet digital.

\section{KESIMPULAN DAN SARAN}

Kesimpulan dari penelitian ini yang mana menghasilkan hasil yang cukup besar pengaruh antar variable untuk mengetahui perilaku niat untuk menggunakan dompet digital. Dengan menyimpulkan bahwa variable perceived of benefit berpengaruh cukup besar terhadap niat untuk menggunakan dompet digital dan Niat untuk menggunakan sangat mempengaruhi aktual untuk menggunakan dompet digital.

Saran yang didapat dari hasil penelitian ini sebagai pedoman bagi perusahaan dalam pengembangan aplikasi domet digital kedepannya. Perusahaan diharapkan dapat membuat aplikasi lebih bernilai dan menambah manfaat dari fitur yang ada sekarang, dengan menambahkan fitur lain yang masih dilaukkan degan pembayaran secara langsung atau cash transaction. Selanjutnya untuk meneruskan penelitian ini maka diharapkan menggunakan variable dan analisis yang lain seperti menambahkan aspek aspek teknologi , lingkungan yang berhubungan dengan adopsi teknologi pembayaran secara digital seperti kualitas layanan, kemudahan bertransaksi dan lain sebagainya.

\section{DAFTAR PUSTAKA}

[1] A. Z. Susilo, M. Iksan Prabowo, A. Taman, A. Pustikaningsih, and A. Samlawi, "A comparative study of factors affecting user acceptance of go-pay and OVo as a feature of Fintech application," Procedia Comput. Sci., vol. 161, pp. 876884, 2019, doi:

10.1016/j.procs.2019.11.195.

[2] Z. Bezhovski, "The Future of the Mobile Payment as Electronic Payment System," Eur. J. Bus. Manag., 2016.

[3] S. Megadewandanu, Suyoto, and Pranowo, "Exploring mobile wallet adoption in Indonesia using UTAUT2: An approach from consumer perspective," Proc. 2016 2nd Int. Conf. Sci. Technol. ICST 2016, pp. 11-16, 2017, doi: 10.1109/ICSTC.2016.7877340.

[4] A. Demuth, Perception Theories, no. 4. 2012.

[5] H.-S. Ryu, "Understanding Benefit and Risk Framework of Fintech Adoption: Comparison of Early Adopters and Late Adopters," Proc. 51st Hawaii Int. Conf. Syst. Sci., pp. 3864-3873, 2018, doi: 10.24251/hicss.2018.486.

[6] E. Taylor, "Mobile payment technologies in retail: a review of potential benefits and risks," Int. $J$. Retail Distrib. Manag., vol. 44, no. 2, 2016, doi: 10.1108/IJRDM-052015-0065.

[7] D. D. Fitri Anggraini Gunawan, "Analisis Pengaruh Iklan Televisi Dan Endorser Terhadap Purchase Intention Pond'S Men Dengan Brand Awareness Sebagai Variabel Intervening," J. Manaj. Pemasar. Petra, vol. 2, no. 1, pp. 1 -14, 2014, doi: 10.7498/aps.62.170507.

[8] A. Ploder and A. Eder, "Semantic Differential," in International Encyclopedia of the Social \& Behavioral Sciences: $\quad$ Second Edition, 2015. 
[9] I. Etikan, "Comparison of Convenience Sampling and

Purposive Sampling," Am. J. Theor. Appl.

Stat., 2016, doi:

10.11648/j .ajtas.20160501.11.

[10] Sugiyono, "Metode Penelitian," Metod. Penelit., 2015.

[11] J. F. Hair, W. C. Black, B. J.

Babin, and R. E. Anderson,

"Multivariate Data Analysis,"

Vectors. 2010, doi: 10.1016/j.ijpharm.2011.02.019.

[12] T. Cleff, Exploratory Data Analysis in Business and Economics. 2014.

[13] M. D. Williams, G. H. Davies, S. Roderick, and M. Clement, "Risk, trust, and compatibility as antecedents of mobile payment adoption," AMCIS 2017 - Am. Conf. Inf. Syst. A Tradit. Innov., vol. 2017-Augus, no. 1989, pp. 110, 2017.

[14] J. Sarwono, "Pengertian Dasar Structural Equation Modeling ( Sem )," J. Ilm. Manaj. Bisnis, pp. 173-182, 2010.

[15] N. Tabri and C. M. Elliott,

"Principles and Practice of Structural Equation Modeling," Can. Grad. J. Sociol. Criminol., 2012, doi: $10.15353 /$ cgjscrcessc.v1i1.25.

[16] D. F. Haynes and N. Cahn, "25131-1-PB.pdf," vol. 1, pp. 56-60, 2012.

[17] C. Lleras, "Path Analysis," Encycl. Soc. Meas., vol. 3, pp. 25-30, 2004, doi: $\quad 10.1016 / \mathrm{B} 0-12-369398-$ 5/00483-7.

[18] Z. Awang, "Validating the Measurement Model: Cfa," Struct. Equ. Model. using amos Graf. , 2014.

[19] Z. Shao, L. Zhang, X. Li, and Y.

Guo, "Antecedents of trust and continuance intention in mobile payment platforms: The moderating effect of gender," Electron. Commer. Res. Appl., vol. 33, p. 100823, 2019, doi: 10.1016/j.elerap.2018.100823.

[20] D. Mcknight, V. Choudhury, and C. ("Chuck") Kacmar, "The Impact of Initial Consumer Trust on Intentions to Transact with a Web Site: $\quad$ A Trust Building Model," J. Strateg. Inf. Syst., vol. 11, pp. 297-323, Dec. 2002, doi: 10.1016/S0963-8687(02)00020-3.

[21] A. F. Agudo-Peregrina, A. Hernandez-Garcia, and F. J. Pascual-Miguel, "Behavioral intention, use behavior and the acceptance of electronic learning systems: Differences between higher education and lifelong learning," Comput. Human Behav., vol. 34, pp. 301-314, 2014, doi: 10.1016/j.chb.2013.10.035. 